\title{
Valuation of Carbon Sequestration and Storage Ecosystem Services in a Tropical Moist Forest of Chocó, Colombia
}

\author{
Víctor Eleazar Mena-Mosquera ${ }^{1}$ (D) \\ Hernán J. Andrade ${ }^{2}$ (i) \\ ${ }^{1}$ Universidad Tecnológica del Chocó, Programa de Ingeniaría Agroforestal, Grupo de Investigación en Agroforestería del Trópico \\ Húmedo Chocoano, Quibdó, Chocó, Colombia \\ ${ }^{2}$ Universidad del Tolima, Departamento de Producción y Sanidad Vegetal, Grupo de Investigación PROECUT, Ibagué, Tolima, Colombia
}

\begin{abstract}
The payment value for the ecosystem service of carbon sequestration and storage in forests and agroforestry systems with cacao (AFS-cacao) from the sub-basin of river Munguidó, Quibdó, Colombia was estimated. The productive activities of highest economic importance (cane, pineapple, plantain, cassava, AFS-cacao, and timber harvesting) were selected, and their financial profit was assessed: net present value (NPV), cost-benefit ratio (B/C), and the internal rate of return (IRR). The payment value for the service was estimated considering the profitability of productive activities and carbon sequestration rate. Minimum and maximum values to pay for reduction of carbon emissions in primary forests, and for carbon sequestration in secondary forests and AFS-cacao are between 4 and 27; 5 and 37; and 9 and $63 \mathrm{U} \$ / \mathrm{Mg} \mathrm{CO}_{2} \mathrm{e}$, respectively.
\end{abstract}

Keywords: Primary and secondary forest, AFS with cacao, profitability.

\section{INTRODUCTION AND OBJECTIVES}

The department of Chocó holds 3,849,174 ha of natural forest, which on average, store $106.8 \mathrm{Mg} \mathrm{C} / \mathrm{ha}$. This represents an opportunity for the communities (both Indigenous and Afrodescendent) to implement schemes for payments for ecosystem services (PES) such as reduction of emissions due to deforestation and degradation (REDD+) (MINAMBIENTE, 2016), thus contributing to their conservation. However, there are not many studies that estimate carbon sequestration and storage in these forests, and even fewer that address to an economic value concerning these ecosystem services.

This region has a great natural richness, which is seen as a source of income, especially from timber products that endanger the stability of the ecosystem and their own conservation (Martínez et al., 2015). According to IIAP (2015), the subbasin of Munguidó river is not excluded from this problem, given that the economy of its communities depends on the agriculture and forest exploitation. Based on that fact, it is important to value the ecosystem services, to encourage and to support REDD+ projects to make a sustainable use of forest and agroforestry systems, and the offer of ecosystem services intending to contribute to the well-being of rural communities (Mena and Andrade, in preparation). According to Puerta et al., (2018), one way to help forest conservation, as well as the goods and services they provide, is through schemes that grant a payment for the ecosystem services.

These ecosystems are highly related to global climate change, given that trees and any other woody perennial vegetation can mitigate this problem by sequestrating $\mathrm{CO}_{2}$ from the atmosphere and, by means of photosynthesis, turning it into biomass and carbon that can be stored for long periods of time (Kongsager and Corbera, 2015). It is estimated that forests and AFS in the world store over 1,000.000 Pg C (1 Pg - Petagram - = $\left.10^{15} \mathrm{~g}\right)$, a fact that makes them important $\mathrm{C}$ sinks and climate change mitigators (Gómez et al., 2018; Serrano et al., 2017).

Payment for ecosystem services is being increased in Latin America, looking forward to reaching environmental (such as carbon sequestration) and conservation goals, and at the same time having positive social impacts (Calvet-Mir et al., 2015; Sánchez and Navarrete, 2017; Wunder et al., 2018). MINAMBIENTE (2017) points out the importance of studies that estimate carbon in biomass in the different forest and agroforest systems, economically valuing it and grant a given PES. The purpose of this current study is to estimate the value to pay for the service of carbon sequestration and storage in forests and AFS-cacao from the sub-basin of Munguidó river, Quibdó, Chocó, Colombia. It is proposed this research hypothesis: the 
profitability of the productive activities of greater economic importance in the sub-basin of Munguido River, determine the value to be paid for the environmental service of carbon storage and fixation in forests and AFS-cacao.

\section{MATERIALS AND METHODS}

\subsection{Description of study area}

The study was carried out in the sub-basin of Munguidó river, located to the left side of Atrato river, in front of the municipal capital of Quibdó ( $\left.5^{\circ} 40^{\prime} 53.7^{\prime \prime} \mathrm{N} ; 76^{\circ} 48^{\prime} 44.4^{\prime \prime} \mathrm{O}\right)$ (Figure 1). The sub-basin has an extension of 61,928 ha, occupying $17.4 \%$ of municipal lands and has an altitude that ranges from $54 \mathrm{~m}$ at its mouth, to $200 \mathrm{~m}$ at its source in the surroundings of Serranía del Baudó (mounts of Baudó) (Municipality of Quibdó, 2005).

The study area corresponds to a life zone of tropical moist forest (bp-T), which has a mean temperature of $26^{\circ} \mathrm{C}$, a relative humidity of $94.6 \%$, and an annual precipitation between 4000 and 10,000 mm (Municipality of Quibdó, 2005; IIAP, 2015).

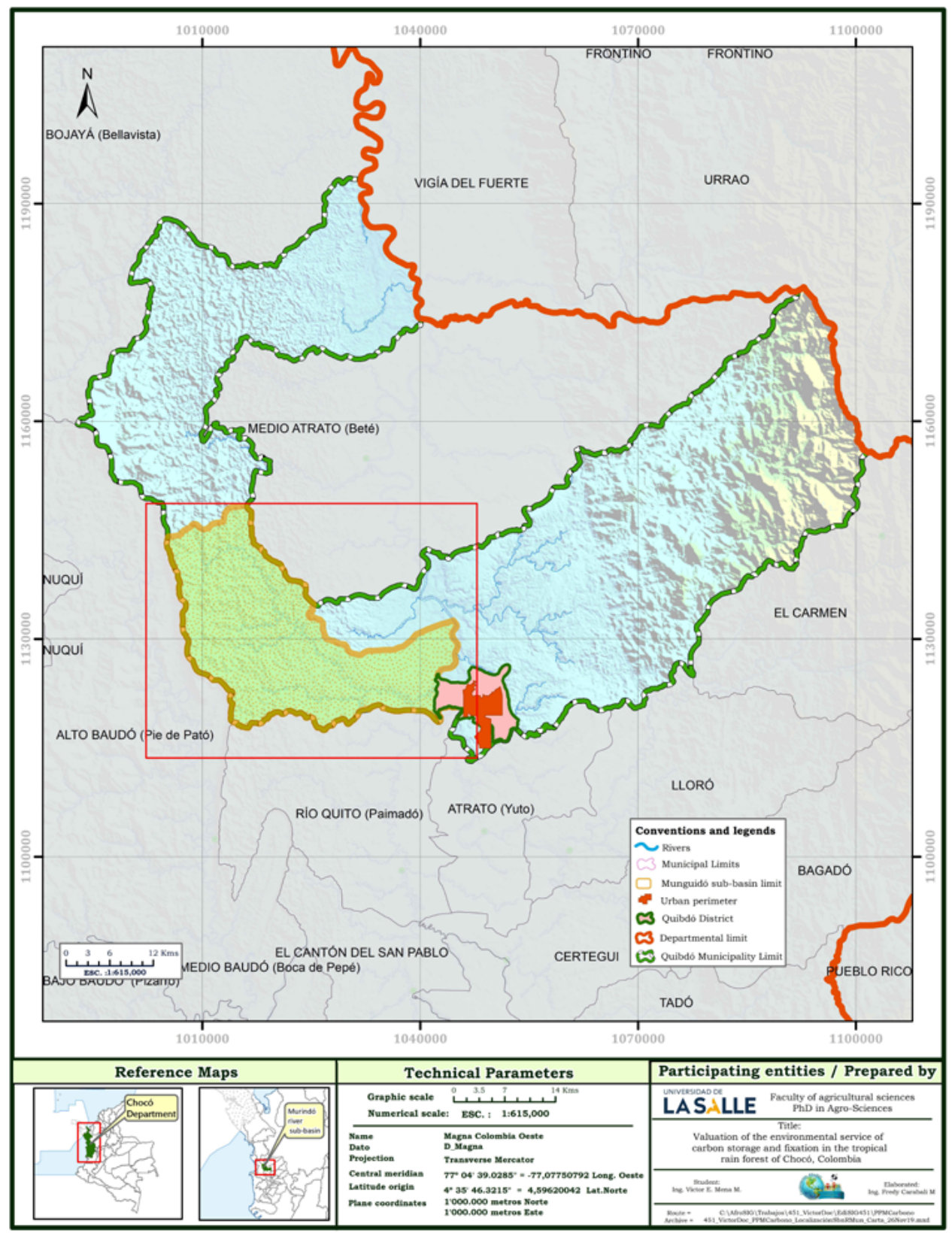

Figure 1. Location of the sub-basin of Munguidó river, municipality of Quibdó, Chocó, Colombia 


\subsection{Productive activity selection}

The productive activities of highest economic importance in the area were selected (monocultures of cane, pineapple, plantain and cassava, agroforestry system with cacao (AFS- cacao), and timber harvesting), considering the municipal agricultural plan of Quibdó and the environmental management plan from Consejo Comunitario Mayor del Medio Atrato (COCOMACIA) (Figure 2).

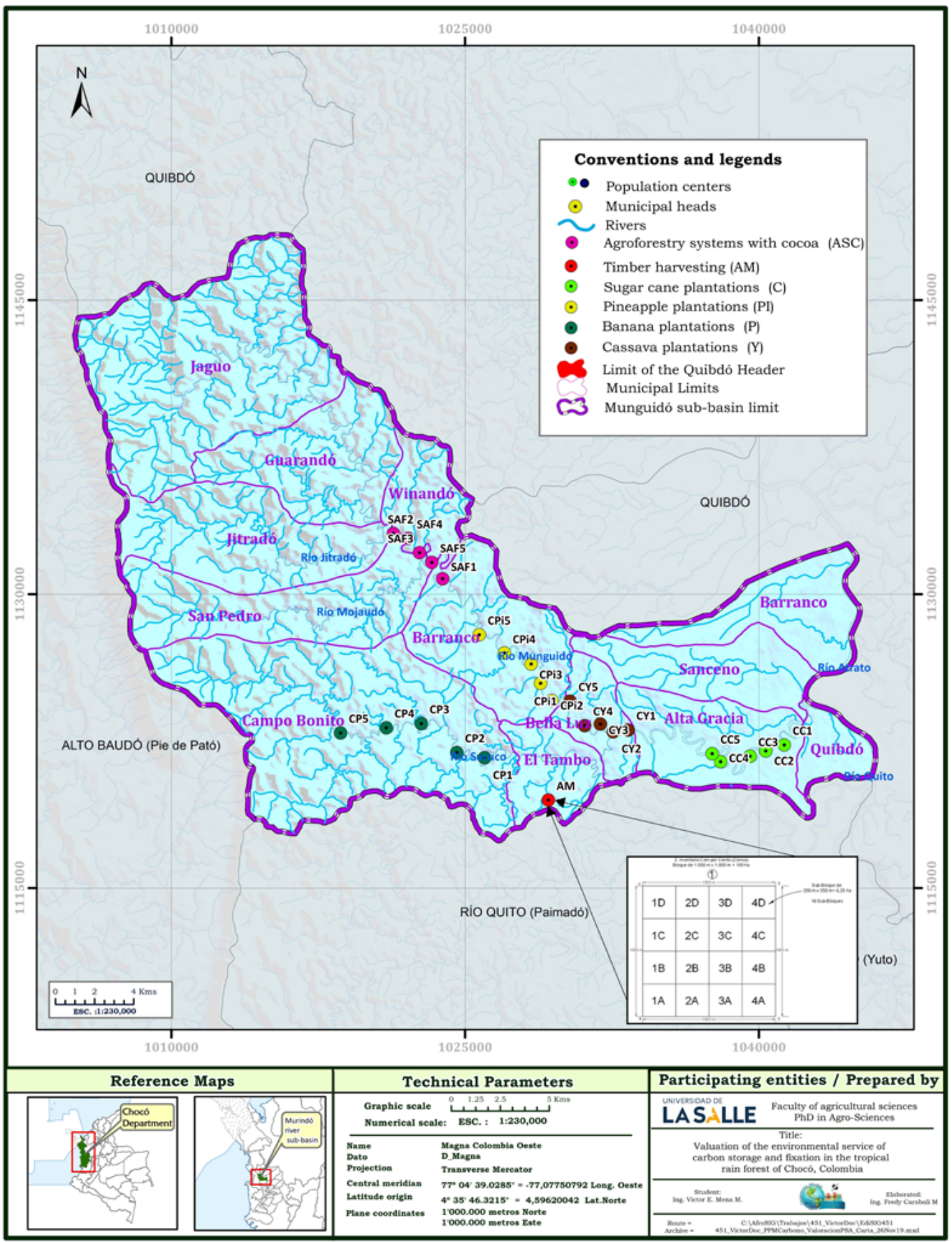

Figure 2. Location of farms where the productive activities of highest economic importance are performed in the sub-basin of Munguidó river, municipality of Quibdó, Chocó, Colombia. 


\subsection{Socioeconomic analysis of productive activities}

A number of 25 farms was selected, five per each productive activity (monocultures and AFS-cacao), and surveys were applied to collect information for socioeconomic analysis and profitability assessment, such as geographic location, family background, plantation distances, workmanship, supplies, material and transport costs, yielding, and sale prices.

From the forests, 100 ha were selected to make a $100 \%$ inventory type (Ministerio de Medio Ambiente, 2002) for the timber harvesting activity. Plant composition of the sub-basin of the Munguidó river was considered to define the species of commercial interest (Mena et al., 2020).

A $1000 \times 1000 \mathrm{~m}$ (100 ha) temporary sampling plot (TSP) was established and divided into 250 × $250 \mathrm{~m}$ sub-blocks, which were identified with numbers and letters. After that, 20 sub-plots of 1000 x $50 \mathrm{~m}$ ( 5 ha) were established and called inventory bands, which went zig-zagging across the TSP from east to west and west to east, and from them the inventory was started (Figure 3).
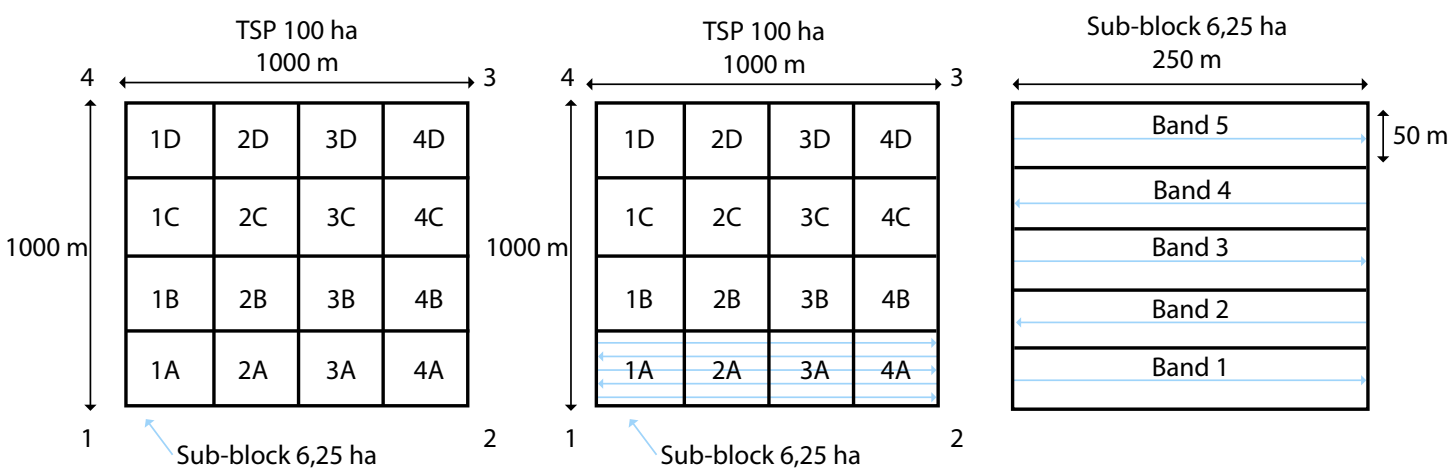

Figure 3. Design of $100 \%$ inventory type for the species of highest commercial interest in the sub-basin of Munguidó river, municipality of Quibdó, Chocó, Colombia

Resolution 0490 of 2016 was considered, which set the trunk diameter at breast height as $(\mathrm{dbh}) \geq 50 \mathrm{~cm}$ as the minimum diameter to cut for timber harvesting, in the area of jurisdiction of the Corporación Autónoma Regional para el Desarrollo Sostenible del Chocó (CODECHOCO) (MINAMBIENTE, 2016). The 100\% inventory was carried out following the directions observed on Figure 3. The following variables of the forest inventory were registered: species, $\mathrm{dbh}$ and commercial height (hc), and others of general interest, filling the corresponding field form.

Stem volume of all inventoried trees was estimated using the basal area and hc. The product obtained for sale in lumberyards were $30-\mathrm{cm}$ wide $\mathrm{x} 15-\mathrm{cm}$ thick $\mathrm{x} 3-\mathrm{m}$ long rakes (Equations 1 and 2).

$A b \cdot=(\pi / \underline{4})^{*} d b h^{2}$

Where; $\mathrm{Ab}=$ basal area $\left(\mathrm{m}^{2}\right)$; dbh $=$ diameter of the trunk at breast height $(\mathrm{m})$

$V c=A b^{*} h c^{*} F . f$.

Where; $\mathrm{Vc}=$ commercial volume $\left(\mathrm{m}^{3}\right) ; \mathrm{Ab}=$ base area $\left(\mathrm{m}^{2}\right)$; $\mathrm{hc}=$ commercial height of the tree $(\mathrm{m})$ (defined as the height where the first branch appears or until reaching a dbh of 30 cm); F.f. = form factor (0.7) (Álvarez, 1971).

\subsection{Costs and benefits of productive activities}

From the information collected on the surveys, the costs per year and productive cycle of each productive activity $(4,4,4,4$ and 20 years for monocultures of cane, pineapple, plantain and cassava and AFS with cacao, respectively) were estimated. In the case of the timber harvesting activity, the costs of management, harvest planning, licenses, assessment and tracing from CODECHOCO, lumberjacks, and trunk transportation were estimated.

(Equation 3)

$C O=\sum_{t=1}^{n}(Q i * P i)$

Where; $\mathrm{CO}=$ operational costs ( $\$ /$ ha/year); $Q i=$ quantity of workmanship and supplies; $P i=$ price of workmanship and supplies ( $\$ /$ ha/year), $\mathrm{n}=$ project duration (years); $\mathrm{t}=$ estimated year.

The gross benefit for the productive cycle of each activity was estimated, this corresponds to the cash received from product sales including timber, minus production costs such as, timber harvesting activity. For sale and supplies prices, the ones found in Quibdó were considered (Equation 4). 


$$
B B=\sum_{t=1}^{n}(Q j * P j)
$$

Where: $\mathrm{BB}=$ Gross benefit $\left(\$ /\right.$ ha/year); $\mathrm{Q}_{\mathrm{j}}=$ quantity of product; $\mathrm{P}_{\mathrm{j}}=$ sale price of product ( $\$ /$ ha/year), $\mathrm{n}=$ Project duration period (years); $\mathrm{t}=$ estimated year.

\subsection{Profitability of productive activities}

The analysis was carried out per each farm and for each of the productive activities. Profitability per year and production cycle based on financial indicators such as net present value, (NPV), cost-benefit ratio $\mathrm{B} / \mathrm{C}$ and the internal rate of return (IRR) was estimated. (Equations 5, 6 and 7).

$N P V=\frac{(B t-C t)}{(1+i) t}$

Where: NPV = net present value (\$); $\mathrm{Bt}=$ total annual benefits in the year $\mathrm{t}(\$ / \mathrm{ha} /$ year); $\mathrm{C}=$ total annual costs in the year $\mathrm{t}$ (\$/ha/year); $\mathrm{i}=$ discount rate $(4.25 \%$ per year Banco de la Republica, 2018).

$B / C=\frac{B T A}{C T A}$

Where: $\mathrm{B} / \mathrm{C}=$ cost-benefit ratio; $\mathrm{BTA}=$ current total benefit (\$/ha); CTA = current total cost (\$/ha).

$I R R=\frac{(B t-C t)}{(1+i) t}=0$

Where: $\mathrm{IRR}=$ internal rate of return (\%); $\mathrm{Bt}=$ total annual benefits in the year $\mathrm{t}(\$ / \mathrm{ha}) ; \mathrm{Ct}=$ total annual costs in the year $\mathrm{t}(\$ / \mathrm{ha}) ; \mathrm{i}=$ discount rate $(4.25 \%$ per year Banco de la Republica, 2018).

\subsection{Estimating the value to pay for ecosystem service of carbon sequestration and storage}

The estimation of the value to pay for the ecosystem service of carbon sequestration and storage was carried out based on the opportunity cost. Minimum and maximum values to pay for the ecosystem service were estimated considering the profitability assessment of the productive activities with the highest economic importance. The income foregone from timber harvesting was assessed, this represented the opportunity for the forest owner and/or the community to make the decision of not cutting it and preserving it to offer the ecosystem service of carbon sequestration and reduce $\mathrm{CO}_{2}$ emissions due to deforestation and forest degradation. The opportunity cost was considered as an estimate of preservation and conservation cost (Meneses and Zamora, 2018; Gandini and Millones, 2019).
Expert consulting was used, carried out by Otárola and Venegas (1999) on the relative importance value (RI) set for ecosystem services, where it was found that carbon sequestration and storage has a $17 \%$ of RI. The value to pay carbon was estimated by using the profitability values of productive activities, potential emission rate of $11.0 \mathrm{Mg} \mathrm{CO}_{2} \mathrm{e} / \mathrm{ha} /$ year for primary forests $(\mathrm{PF})$, and carbon sequestration rates of 2.2 and $1.3 \mathrm{Mg} \mathrm{C} / \mathrm{ha} /$ year for secondary forest (SF) and AFS with cacao, respectively. The value of the potential emissions was estimated considering the reduction of the deforestation rate of these primary forests to zero; while the carbon fixation rates were calculated as the ratio between carbon storage and the age of the systems (Mena and Andrade, in progress).

\section{RESULTS}

\subsection{Socioeconomic analysis of productive activities}

From the families that were surveyed, $100 \%$ live in the productive units and have between 3 and 5 members. Crops are established and mostly grow at a distance of 50 to 150 $\mathrm{m}$ away from the shore of rivers and streams. Lands are flat lightly steeped, with slopes of 5 to $20 \%$.

Cacao is managed with provisional plantain and banana shade, and permanent shade from fruit and timber species. Plantain cultivations are managed either in monocultures or AFS with cacao; whereas cassava, pineapple and cane are produced in monoculture with no trees. The most common management activities are weed control, fertilization and pest control, fertilization is carried out with a mix of poultry manure and an organic fertilizer produced by ant nests at a rate of $200 \mathrm{~g} / \mathrm{plant} / \mathrm{year}$ in all the crops. The main pests treated are the army ant (Atta sp), and diseases such as black sigatoka (Mycosphaerella fijiensis Morelet), moniliasis (Moniliophthora roreri) and frostly pod rot (Moniliophthora perniciosa).

A total of $70 \%$ of family incomes comes from labor, the day's wage is $\$ 35,000^{1}$ Colombian Pesos - COP $(\$ 20,000$ in cash and $\$ 15,000$ in food), and $100 \%$ of supplies and materials are bought in Quibdó. Cacao and cane production is completely sold in Quibdó, while $90 \%$ of plantain, pineapple and cassava are sold and $10 \%$ is for self-consumption. The only transportation means in the area is fluvial on off-board engine boats. Transportation rates per bulk and ration is $\$ 10,000$, while the rate for the hundred canes is $\$ 20,000$.

The $100 \%$ of the forests have been granted to the community councils of the area of study by collective land titles. According with current legislation for timber harvesting and commercialization, the community council must request a permission from CODECHOCO with a forest harvesting and ${ }^{1}$ Exchange rate $\$ 3175 / \mathrm{U} \$$ on November 2018. 
management plan, additional to a payment to the institution for its assessment and tracing, and a laissez-passer.

The request for timber harvesting is made in volume units. Each timber block, called rastra is sold by $\$ 35,000$ each $\left(1 \mathrm{~m}^{3}=5.6\right.$ blocks $)$. The $100 \%$ inventory type found a total of 423 individuals and a total usable volume of 3,228.2 $\mathrm{m}^{3}$ in the nine species of highest commercial interest in 100 ha (Figure 4). This means that every exploitable tree has $7.6 \mathrm{~m}^{3}$ on average, from which $75 \%$ become logs and
$25 \%$ waste from the operation, left on the field. The species with the highest abundance and availability of exploitable wood are Brosimum utile, Crysophyllum argenteum, and Schweilera pittieri (Figure 4). Exploitation of timber available in the inventoried forest requires 678 days ( 2.3 years), with the participation of work teams composed of one lumber and two assistants for a yield of 20 blocks a day. Total net exploitable volume is $2,421.2 \mathrm{~m}^{3}$ (13,559 blocks), which makes a net income of $\$ 89,338,920$.

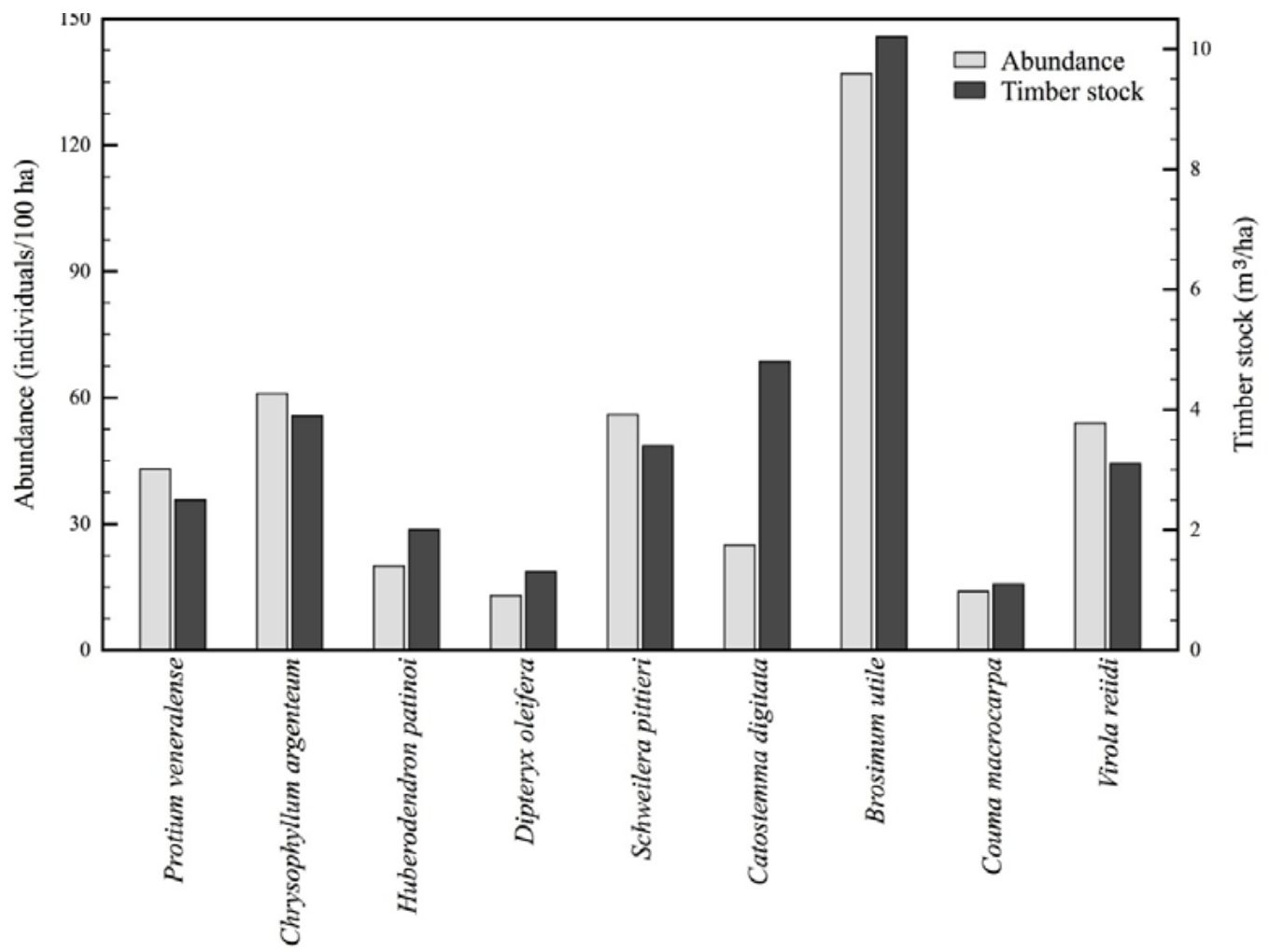

Species

Figure 4. Abundance and volume of exploitable timber from commercial interest species in tropical moist forest from the sub-basin of Munguidó river, municipality of Quibdó, Chocó, Colombia.

\subsection{Costs and benefits of productive activities}

Plantain crops had the highest net profit $(\$ 2,920,500 / \mathrm{ha} /$ year), whereas timber harvesting showed the lowest $(\$ 297,796 /$ ha/year). Pineapple crops reached the highest gross profit
$(\$ 7,727,000 /$ ha/year $)$, but also the highest operational cost $(\$ 8,597,500 /$ ha/year). Timber harvesting was the activity with the lowest operational cost and gross profit $(\$ 1,284,087$ and $\$ 1,581,883 / \mathrm{ha} /$ year, respectively). All productive activities showed gross profits higher than the operational costs (Table 1).

Table 1. Operational costs and profit from the productive activities of highest economic importance in the sub-basin of Munguidó river, municipality of Quibdó, Chocó, Colombia.

\begin{tabular}{lccc}
\multicolumn{1}{c}{ Productive Activity } & Operational Costs & Gross Profit & Net Profit \\
\cline { 2 - 4 } & & $\$ 1000 /$ ha/year & 2,921 \\
Plantain crops & 3,530 & 6,450 & 2,202 \\
Cassava crops & 3,978 & 6,180 & 1,741 \\
Cane crops & 6,172 & 7,913 & 989 \\
Cacao crops & 2,671 & 3,660 & 871 \\
Pineapple crops & 7,727 & 8,598 & 298 \\
Timber harvesting & 1,284 & 1,582 & \\
\hline
\end{tabular}




\subsection{Profitability of productive activities of highest economic interest}

Productive activities showed a mean profitability with a NPV of $\$ 578,055 /$ ha/year; a B/C of 1.1 and IRR de $31.0 \%$. Cane, pineapple, plantain and cassava crops showed a mean of $\$ 757,231 /$ ha/year, 1.1 and $35 \%$; SAF with cacao showed $\$ 203,440 /$ ha/year, 1.1 and 6.4\%; and timber harvesting: $\$ 23,969$ / ha/year, 1.2 and $32.8 \%$ (NPV, B/C and IRR, respectively). On the other hand, the highest profitability was seen in cane crops, followed by pineapple, plantain, cassava, wood exploitation and AFS with cacao (Table 2).

Table 2. Profitability of the productive activities of highest economic importance in the sub-basin of Munguidó river, municipality of Quibdó, Chocó, Colombia.

\begin{tabular}{|c|c|c|c|c|}
\hline \multirow{2}{*}{ Productive activity } & \multicolumn{4}{|c|}{ Financial Indicators } \\
\hline & VAN (\$1000/ha/year) & VAN (U\$/ha/year) & $\mathbf{R} \mathbf{B} / \mathbf{C}$ & TIR (\%) \\
\hline Plantain crops & 1,439 & 453 & 1.3 & 56.6 \\
\hline Cassava crops & 642 & 202 & 1.1 & 24.0 \\
\hline Cane crops & 585 & 184 & 1.1 & 49.2 \\
\hline Cacao crops & 363 & 114 & 1.1 & 13.5 \\
\hline Pineapple crops & 203 & 64 & 1.1 & 6.4 \\
\hline Timber harvesting & 236 & 74 & 1.2 & 33.8 \\
\hline Mean & 578 & 182 & 1.1 & 31.0 \\
\hline
\end{tabular}

Interest rate 4.25\%/year Banco de la República, 2018; Exchange rate: \$3175/U\$ November, 2018.

\subsection{Value to pay for ecosystem service of carbon sequestration and storage}

Ecosystem services presented minimum and maximum values to pay of 64.0 and $453.6 \mathrm{U} \$ /$ ha/year, respectively. This was given by profitability, in terms of high and low NPV. On the other hand, carbon sequestration and storage services showed minimum and maximum values to pay of 11.5 and $81.5 \mathrm{U} \$ /$ ha/year, respectively. Minimum and maximum values to pay for carbon emissions in PF and carbon sequestration in SF and SAF with cacao were: 4 and 27; 5 and 37; and 9 and $63 \mathrm{U} \$ / \mathrm{Mg} \mathrm{CO}_{2} \mathrm{e}$, respectively. AFS with cacao showed the highest value to pay (36 $\mathrm{U} \$ / \mathrm{Mg} \mathrm{CO}_{2} \mathrm{e}$ ), exceeding PF and SF values in 57 and $41 \%$, respectively (Figure 5).

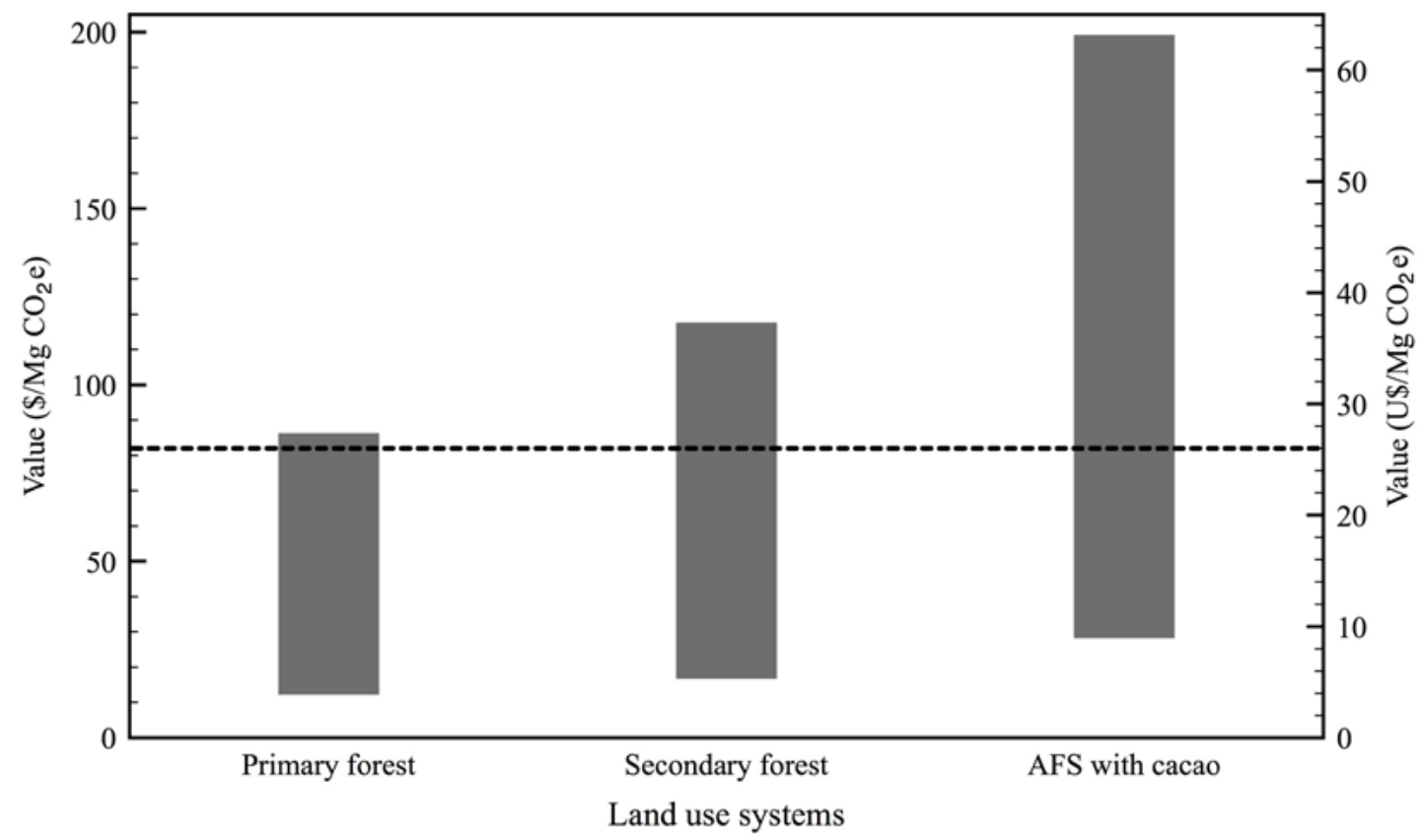

Figure 5. Values to pay for carbon sequestration and storage in primary forest, secondary forest and AFS with cacao in the sub-basin of Munguidó river, municipality of Quibdó, Chocó, Colombia. 


\section{DISCUSSION}

\subsection{Profitability of productive activities}

Profitability of productive activities of highest economic interest in the sub-basin of Munguido river is due to the demand and good price of products in Quibdó market. However, these net benefits are lower than those estimated by Diniz et al. (2018) in Brazilian Amazon: 3886, 1081, 874 and $107 \mathrm{U} \$ /$ ha/year for plantain, cacao, cassava and sugar cane, respectively. In Ghana, Asare et al. (2014) estimated in 1.19 and $40.0 \%$ the total benefit-cost ratio and the internal rate of return of cacao crops, which slightly exceeds the profitability estimated on this current study. Contrasts my take place due to several social and infrastructural factors. Additionally, in Chocó, the financial profit from timber harvesting turned out to be significantly lower (U $\$ 74 /$ ha/year) than the estimated for Brazilian Amazon in 2009, which comes around U\$330/ ha/year (Diniz at al., 2018).

\subsection{Opportunity cost for carbon sequestration and reduction of emissions}

The opportunity cost to preserve the forest and stop earning the income from timber harvesting (NPV \$235,969/ ha/year and U\$74/ha/year), is lower than the one resulting from cane, pineapple, plantain, cassava and AFS with cacao (NPV \$646,473/ha/year and U\$203/ha/year). Opportunity costs estimate what could be achieved using the resources in another way, for example in agriculture (Cartier, 2017; Casiano and Paz, 2017). Results show that preserving the Brazilian Amazon forest in its current state, allows carbon storage and sustaining an existence value of around U\$2026/ha (Diniz et al., 2018).

Values shown above are the basis for estimating the value to pay for the ecosystem services of carbon sequestration and storage and are comparable to those reported by Martínez et al. (2015) in four municipalities of the department of Chocó. Despite profitability of the wood exploitation activity is lower than that of other productive activities in the area of study, it facilitates and encourages the awareness of timber producers towards the preservation of forests and a possible change of productive activity.

\subsection{Value to pay for the ecosystem services of carbon sequestration and storage}

The estimation of values to pay for ecosystem services through the activities of highest economic importance in the sub-basin of Munguidó river, makes that such value represents the context of the economic reality of the area of study. The ecosystem service of carbon sequestration and storage showed values similar to the estimations by Segura (1999): between 42 and $100 \mathrm{U} \$ /$ ha/year in farms of Corinto, Costa Rica. These values are essential to assess the feasibility of carbon projects (Khanal and Devkota, 2020), since they are the basis to compare with the international price of carbon and the transaction costs.

Zelek and Shively (2003) claim that the opportunity cost of carbon storage in land use change varies between $\mathrm{U} \$ 12.1$ and $\mathrm{U} \$ 229 / \mathrm{Mg} \mathrm{CO}_{2}$, where AFS show a lower value than systems based only on trees. Despite results are not totally comparable due to methodological and temporality differences, they allow an appropriate valuation of the forests to look for adequate preservation options. Silva et al. (2019) have an estimate shadow price of $\mathrm{U} \$ 16 / \mathrm{Mg} \mathrm{CO}_{2}$ for carbon sequestration in Brazilian Amazon.

The international average price of carbon for 2019 (U\$26 $\left.\mathrm{MgCO}_{2} \mathrm{e}\right)$ is within the ranges that show the land use systems assessed in the study area. These costs are similar to the ones reported by De la Peña et al. (2010) in Ciénaga Grande de Santa Marta; and by Sarithirathai \& Barbier (2001) in the province of Surat Thani, South Thailand. Ranges for value to pay in this current study, become a negotiation tool for community councils of the study area considering the possibility of ESP project implementation and carbon sale projects.

Given that timber harvesting activity is one of those with the lowest profitability, it becomes a strong argument to justify the necessity to reduce or stop deforestation, preserve forests, sell carbon credits and thus enhancing agricultural production activities (Andersson et al., 2018). The opportunity cost of suspending timber harvesting is $2.7: 1$, reason why it is more convenient for the community councils sub-basin of Munguidó river to sell the ecosystem service of carbon sequestration and storage, which will increase their income. This value is similar to the one reported by Bautista \& Torres (2003) in Ejido Noh Bec, Quintana Roo, México; who estimated an opportunity cost of 3.5:1 between the ecosystem service of carbon sequestration and storage and the timber harvesting. With the results found in this study, the hypothesis of that the value to be paid for the environmental carbon storage and fixation service is dependent on the profitability of the productive activities of greater economic importance in the study area has been proved.

AFS are presented as an option when environmental and other benefits are looked for small producers. However, it is very difficult to obtain them in practice (Anderson and Zerriffi, 2012). Premiums paid for differenced cacao and ecosystem services can improve the situation. Asare et al. (2014) estimated that the cost-benefit relation increases 
between 4 and 18\%, and the internal rate of return between 9 and $28 \%$. When AFS with cacao obtain premium prices to cacao, a payment for carbon sequestrated and other ecosystem services is received. AFS are also encouraged for their other environmental benefits, such as their use in strategies for the connection of forest fragments (Asare et al., 2014). Just the same, it has been proven that an increase in the coverage of the canopy does not affect significantly the production of cacao. That way, Abou Rajab et al. (2016) estimated that, by increasing this coverage from 50 to $93 \%$, cacao production remained steady. Despite the benefits of these AFS, they must not be encouraged as an option to change native forests, since the most focused strategies towards preservation should be addressed to natural forests. In the case of converting these forests into cacao fields, Leuschner et al. (2013) estimated a carbon loss in biomass of around $130 \mathrm{Mg} / \mathrm{ha}$, adding some $50 \mathrm{Mg} / \mathrm{ha}$ if the soil is considered.

The IPPC (2014) claims that mitigation and adaptation actions are required to answer effectively to climate change. These two actions can be promoted in the forest and agroforestry sector for a climate-friendly development of the rural areas in order to increase mitigation and ecological resilience. However, it is necessary that donors support more holistic projects and founded upon methods based on the territory (Kongsager and Corbera, 2015). The strategies for a lower rural emission rate must consider the combination of landscapes, institutions and main actors, but it is also necessary to highlight on a leverage and integrate wider (Nepstad et al., 2015).

In Colombia, taxes and emission reduction goals can achieve significant reductions of $\mathrm{CO}_{2}$ (Calderón et al., 2016). For example, it is possible to include carbon sequestration and storage in forests (Carvajal and Andrade, 2020; SeguraMadrigal et al., 2020) and agroforestry systems with cacao (Somarriba et al., 2013; Marín et al., 2016). In this context, these estimations provide elements for a carbon project proposal, such as those REDD+ (Lee and Pistorius (2015) that grant a benefit to local inhabitants.

\section{CONCLUSIONS}

Inventories of valuable timbers in the forests of the subbasin of Munguidó river are still in a stable condition due to the management of community councils. However, it is important to implement measures that lead to their protection and the improvement of the socioeconomic conditions of local inhabitants.

The productive activities from the sub-basin of Munguidó river showed low profitability, which, along with the current international price of carbon, bring a feasible potential for launching projects of carbon emission reduction in primary forests and carbon sequestration in secondary forests and AFS with cacao in the sub-basin of Munguidó river. Particularly, the low profitability of timber harvesting from forests makes protection projects more appealing, which will also improve the income of local families.

This study presented a methodological approach to valuate the service of carbon storage and fixation, which can be applied in a contextualized way to the local, regional and national economic reality of the Neotropics. This methodology can be used at any scale, taking as inputs the financial profitability and the carbon fixation rate, either in biomass or soils, of the most economically important activities.

\section{SUBMISSION STATUS}

Received: 06 Nov. 2020

Accepted: 07 Oct. 2021

Associate editor: Emanuel José Gomes de Araújo (1)

\section{CORRESPONDENCE TO}

\section{Víctor Eleazar Mena-Mosquera}

Universidad Tecnológica del Chocó Diego Luís Córdoba, Quibdó, Chocó, Colombia.

e-mail: memovie@gmail.com

\section{AUTHORS' CONTRIBUTIONS}

Víctor Eleazar Mena-Mosquera: Conceptuallization (Equal); Data curation (Lead); Formal analysis (Equal); Funding acquisition (Lead); Investigation (Equal); Methodology (Equal); Project administration (Lead).

Hernán J. Andrade: Conceptualization (Equal); Formal analysis (Equal); Investigation (Equal); Methodology (Equal); Software (Equal); S upervision (Lead); Validation (Lead); Visualization (Lead); Writing-original draft (Equal); Writingreview \& editing (Equal).

\section{REFERENCES}

Abou Rajab Y, Leuschner C, Barus H, Tjoa A, Hertel D. Cacao Cultivation under Diverse Shade Tree Cover Allows High Carbon Storage and Sequestration without Yield. Losses. PLoS One. 2016; 11(2) 23-32. DOI:10.1371/journal.pone.0149949.

Álvarez, J .J .E. (1971). Tablas de volúmenes para árboles en pie, volúmenes con corteza en metros cúbicos. Región La Teresita, Choco. INDERENA. 14p.

Anderson EK, Zerriffi H. Seeing the trees for the carbon: agroforestry for development and carbon mitigation. Climatic Change 2012; 115:741-757. DOI 10.1007/s10584-012-0456.

Andersson KP, Smith SM, Alston LJ, Duchelle AE, Mwangi E, Larson AM et al. Wealth and the distribution of benefits from 
tropical forests: Implications for REDD. Land use policy 2018; 72 : 510-522. DOI: 10.1016/j.landusepol.2018.01.012.

Asare T, Afari-Sefa V, Osei-Owusu Y, Pabi O. Cocoa agroforestry for increasing forest connectivity in a fragmented landscape in Ghana. Agroforest System 2014; 88:1143-1156. DOI 10.1007/ s10457-014-9688-3.

Bautista J, Torres J. Valoración económica del almacenamiento de carbono del bosque tropical del ejido Noh Bec, Quintana Roo, México. Revista Chapingo. Serie Forestales y del ambiente 2003; 9 (1): 69-75. http://www.scielo.org.mx/scielo.php?script=sci_ nlinks\&pid $=$ S1405-0471201700020022500005\&lng=en

Calderón S, Álvarez, AC, Loboguerrero, AM; Arango S, Calvin K; Kober $\mathrm{T}$ et al. "Achieving $\mathrm{CO} 2$ reductions in Colombia: Effects of carbon taxes and abatement targets", Energy Economics 2016; 56: 575-586.

Calvet-Mir L, Corbera E, Martin A, Fisher J, Gross-Camp N. Payments for ecosystem services in the tropics: a closer look at effectiveness and equity. Curr. Opin. Environ. Sustain 2015, 14:150162. https://doi.org/10.1016/j.cosust.2015.06.001.

Cartier EN. ¿De qué hablamos cuando hablamos de Costo de Oportunidad?. Costos y Gestión 2017; 93: 58-79. https://dialnet. unirioja.es/servlet/articulo? codigo $=6154750$.

Carvajal-Agudelo, BN; Andrade, HJ. Captura de carbono en biomasa de sistemas de uso del suelo, municipio de Yopal, Casanare, Colombia. Orinoquia 2020; 24(1): 13-22.

Casiano M, Paz F. Estructura anidada para la estimación de costos de oportunidad para REDD+ y RETUS. Elementos de Política Pública 2017; 1(2): 103-130. http://www.elementospolipub.org/ ojs/index.php/epp/article/view/18/0.

Consejo Comunitario Mayor del Medio Atrato (COCOMACIA). Plan de Manejo Ambiental del Concejo Comunitario Mayor del Medio Atrato: Documento de caracterización; 2000.

De la Peña A, Rojas C, De la Peña M. Valoración económica del manglar por el almacenamiento de carbono, Ciénaga Grande de Santa Marta. Clío América 2010; 133-150.

Diniz MB, Alves VDP, Diniz MJT. ¿Refleja el uso de la tierra en la Amazonia un fallo del mercado? Un análisis de los servicios ambientales de la Amazonia desde la perspectiva del costo de oportunidad. Revista CEPAL 2018; 126:109-129.

Gandini PA, Millones A. Percepción y valoración de servicios ambientales de las áreas protegidas de Puerto Deseado, Santa Cruz. Informes Científicos Técnicos - UNPA 2019; 11(1): 28-35. https:// doi.org/10.22305/ict-unpa.v11i1.771.

Gómez E, Rousseau X, Celentano D, Fariñas H, Gehring C. Efecto de la riqueza de especies y estructura de la vegetación en el almacenamiento de carbono en sistemas agroforestales de la Amazonía, Bolivia. Revista de Biología Tropical 2018; 66(4): 14811495. http://dx.doi.org/10.15517/rbt.v66i4.32489.

Instituto de Investigaciones Ambientales del Pacifico (IIAP). Plan Integral Integral de Cambio Climático Departamento del Chocó. IIAP. 2015. https://www.minambiente.gov.co/index.php/noticiasminambiente/2368-minambiente-e-iiap-lanzan-nuevo-plan-decambio-climatico-para-choco.

Khanal Y, Devkota, BP. Farmers' responsibilization in payment for environmentalservices: Lessons from community forestry in Nepal. Forest Policy and Economics 2020; 118 DOI: 10.1016/j. forpol.2020.102237.
Kongsager R, Corbera E. Linking Mitigation and Adaptation in Carbon Forestry Projects: Evidence from Belize. World Development 2015; 76: 132-146

Lee D, Pistorius T. The impacts of international REDD+ finance. 2015.

Leuschner, C., Moser, G., Hertel, D., Erasmi, S., Leitner, D., Culmsee, $\mathrm{H}$ et al. Conversion of tropical moist forest into cacao agroforest: consequences for carbon pools and annual $\mathrm{C}$ sequestration Agroforest. Systems 2013; 87, 1173-1187.

Marín MP, Andrade HJ, Sandoval AP. Fijación de carbono atmosférico en la biomasa total de sistemas de producción de cacao en el Departamento del Tolima, Colombia. Rev. U.D.C.A Act. \& Div. Cient. 2016; 19(2): 351-360.

Martínez M, Torres JJ, Medina HH. Aprovechamiento forestal maderable en cuatro municipios del departamento de Chocó, Colombia. Investigación Agraria y Ambiental 2015; 6(2): 57-73. https://doi.org/10.22490/21456453.1405.

Mena, VE, Andrade HJ, Torres JJ. Composición florística, estructura y diversidad del bosque pluvial tropical de la subcuenca del río Munguidó, Quibdó, Chocó, Colombia. Entramado 2020; 16(1): 204-215. http://dx.doi.org/10.18041/1900-3803/entramado.1.6109.

Mena, VE, Andrade HJ. Potencial de reducción de emisiones y captura de carbono en bosques y sistemas agroforestales con cacao de la subcuenca del río Munguidó, municipio de Quibdó, Chocó, Colombia. Universidad de La Salle. Bogotá. (En preparación).

Meneses R, Zamora NS. Valoración económica del servicio de fijación y almacenamiento de carbono en la cobertura forestal - Parque Nacional del Huascarán. Cátedra Villarreal 2018; 6(1): 67-74. https://doi.org/10.24039/cv201861255.

Ministerio de Ambiente y Desarrollo Sostenible. MINAMBIENTE. Decreto 870 del 25 de mayo de 2017: Por el cual se establece el Pago por Servicios Ambientales y otros incentivos a la conservación. Bogotá, D.C; 2017.

Ministerio de Ambiente y Desarrollo Sostenible. MINAMBIENTE. Resolución 0490 de 2016: Por la cual se fija el cupo global para el otorgamiento de permisos y autorizaciones de aprovechamiento forestal de bosques naturales en la jurisdicción de la Corporación Autónoma Regional para el Desarrollo Sostenible del Chocó (CODECHOCO), y se dictan otras determinaciones. Bogotá, D.C; 2016

Ministerio de Medio Ambiente. Guías Técnicas Para la Ordenación y el Manejo Sostenible de los bosques naturales; 2002. http://www.itto.int/ files/itto_project_db_input/2021/Technical/pd8-97-1 rev2(F)_s.pdf. Municipio de Quibdó. Plan de Ordenamiento Territorial - Municipio de Quibdó: Diagnostico de estructura general del territorio. Quibdó; 2005. https://www.quibdo-choco.gov.co/Proyectos/NuestrosPlanes/ Plan de Ordenamiento Territorial - Municipio de Quibdó.pdf.

Nepstad D, Irawan S, Bezerra T, Boyd, Stickler C, Shimada J et al. More food, more forests, fewer emissions, better livelihoods: linking REDD+, sustainable supply chains and domestic policy in Brazil, Indonesia and Colombia, Carbon Management 2013; 4(6): 639-658, DOI: 10.4155/cmt.13.65.

Otárola M, Venegas I, Alfaro M. Sistemas de compensación de servicios ambientales para los robledales de la Cordillera de Talamanca. Revista de Ciencias Ambientales 2000; 18(1): 37-59. https://doi.org/10.15359/rca.18-1.5.

Puerta JF, Yánez MM, Medina R. Los sistemas de pagos por servicios ambientales de los bosques, una necesidad para el desarrollo 
sostenible. Universidad y Sociedad 2018; 10(2): 209-216. http:// rus.ucf.edu.cu/index.php/rus.

Sánchez O, Navarrete G. La experiencia de Costa Rica en el pago por servicios ambientales: 20 años de lecciones aprendidas. Revista de Ciencias Ambientales 2017; 51(2): 195-214. http://dx.doi. org/10.15359/rca.51-2.11.

Segura MA. Valoración del servicio de almacenamiento y fijación de carbono en bosques privados del Área de Conservación Cordillera Volcánica Central. Tesis de Maestría, CATIE, Turrialba. Costa Rica; 1999. Retrieved from http://orton.catie.ac.cr/repdoc/A0178e/ A0178e.pdf.

Segura MA, Andrade, HJ, Sierra E. Diversidad florística y captura de carbono en robledales y pasturas con árboles en Santa Isabel, Tolima, Colombia. Revista de Biología Tropical 2020; 68(2): 383-393.

Serrano E, Nuñez M, Valleter E. Respiración de dióxido de carbono de suelo, en bosque tropical húmedo - Gamboa Panamá. I+D
Tecnológico 2017: 13(2): 49-54. https://revistas.utp.ac.pa/index. php/id-tecnologico/article/view/1714.

Silva, FdF; Perrin, RK; Fulginiti, LE. The opportunity cost of preserving the Brazilian Amazon forest. Agricultural Economics 2019; 50(2): 219-227. https://doi.org/10.1111/agec.12478

Somarriba E, Cerda R, Orozco L, Cifuentes M, Dávila H, Espin $\mathrm{T}$ et al. Carbon stocks and cacao yields in agroforestry systems of Central America. Agri Ecosyst Environ 2013; 173:46-57. https:// doi: 10.1016/j.agee.2013.04.013.

Wunder S, Brouwer R, Engel S, Ezzine de Blas D, Muradian R, Pascual $U$ et al. From principles to practice in paying for nature's services. Nat. Sustain 2018; 1, 145-150. https://doi.org/10.1038/ s41893-018-0036-x.

Zelek, CA; Shively, GE. Measuring the Opportunity Cost of Carbon Sequestration in Tropical Agriculture. Land Economics 2003; 79(3): 342-354. 